\title{
AN INTERNATIONAL RESEARCH CONSORTIUM ON ENERGY SECURITY AND HEALTH PROTECTION IN UIRRAINE: THE U. S. PERSPECTIVE
}

\author{
Hryhorczuk D. 0.1,2, Kozyclkyj T.2, Iwanik K. N.', Edison M.', \\ Dardynsky 0.1, Dardynskaia I.2
}

\author{
'Center for Global Health, University of Illinois College of Medicine, Chicago, USA \\ ${ }^{2}$ School of Public Health, University of Illinois at Chicago, USA
}

The University of Illinois at Chicago, in partnership with the Ukrainian Institute of Occupational Health; Marzeiev Institute for Hygiene and Medical Ecology; Institute for Pediatrics Obstetrics and Gynecology; Institute of Endocrinology and Metabolism; and National Scientific Centers for Radiation Medicine; embarked on the planning for an international research consortium to address issues of Energy Security and Health Protection in Ukraine. Support for the planning of this Global Environmental and Occupational (GEO) Health Hub was provided by the U.S. National Institutes of Health Fogarty International Center. In this paper we provide the current U.S. perspective on success factors and challenges for the implementation of such a consortium.

Key words: international research consortium, health protection, energy security, lateral alliance

\section{Introduction}

The University of Illinois at Chicago has engaged in collaborative research, research training, and capacity building with Ukrainian partners in the National Academy of Medical Sciences for the past seventeen years. This collaboration was supported, in large part, by «International Training and Research in Environmental and Occupational Health (ITREOH)» grants from the Fogarty International Center at the U. S. National Institutes of Health. These grants supported the training of over 25 Ukrainian Visiting Scientists, supported pilot grant research programs, and hosted international conferences and workshops in Ukraine on a wide variety of occupational and environmental health topics. These ITREOH grants were awarded on a competitive basis to U.S. universities, such as the University of Illinois. The universities then supported the costs of providing the research training for scientists from low and middle-income (LMIC) countries. The strategy of the Fogarty Center has now shifted towards directly supporting research in these countries. The U.S. universities, which before had played a leading role, will now play primarily a supporting role by providing research training and capacity building that is targeted towards the research agenda of the LMIC country.

Together with our Ukrainian partners, we successfully competed for a GEOHub planning grant. The specific aims of the planning grant were to 1 ) develop a strategic plan for the GEOHealth Hub; 2) conduct an assessment of needs and opportunities that addresses the science needed to support relevant policy development in Ukraine; 3) update Ukraine's National Environmental Health Action Plan; 4) provide academic participation in the development of the National Occupational Health Action Plan; 5) mine data from the «Family and Children of Ukraine» study to set priorities for policy on children's environmental health; 6) form bi-national research teams to plan future research programs; 7 ) use professional journals to facilitate the planning; 8) conduct outreach to potential partners in Belarus, Serbia, and Poland; and 9 ) evaluate the success of the planning process. To accomplish these aims we held two meetings of our international partners that were hosted by the Institute of Occupational Health of NAMS, which is the lead Ukrainian partner in the planned GEOHub. These meetings were held May 20 and 30, 2013 and again on June 19 and 20, 2014. At the initial meeting we decided on «Energy Security and Health Protection» as the research theme of the consortium. During the second meeting we extended our network to include research partners from Poland, Serbia, and Belarus. Given the Fogarty Center's shift in emphasis on direct support of LMIC research programs, the final decisions on the structure of the consortium, inclusion of research partners, and selection of research studies is Ukraine's. As part of our role in supporting the development of the GEOHub consortium, we reviewed the experiences of several current international collabora- 
tions to identify the challenges faced and strategies adopted for successful collaboration. This review will highlight key themes when undertaking such research collaborations in areas of consortia organization, operation, finances, communication, data sharing and dissemination. We anticipate that these will provide useful guidance for successful future research ventures and consortia establishments such as the GEOHealth Hub.

\section{Why collaborate?}

International partnerships and joint ventures are not new in the realm of scientific research. Countries around the world seek to collaborate with other countries to both gain and sustain access to recognition within the professional community [3, 7, 15]. Those countries often seek to work together with the leading countries to improve quality of research. Due to the financial demands of scientific research, international collaborations enable research teams to join efforts and become eligible for additional funding or attract donors to invest in the collaborative research. In addition to direct economic benefits, research partnerships also build ambition, bring about a better interconnectedness between the scientific collaborating communities, and also form good relations to develop additional links to enhance collaborations $[3,7,14]$. Additional benefits to international research collaboration are identified by Ansari et al. and include:

- Greater scientific gains as researchers may acquire a larger and more diverse study population, and experience variations in health policies and structural settings to better understand the scope of issues.

- Expertise of investigator team as investigators complement each other in contributing multiple perspectives, theoretical approaches, disciplines, and educational backgrounds.

- Funding opportunities may increase, as certain grants are available to research collaborations that are not open for individual studies.

- Generalizability of findings improves with a larger sample size drawn from multiple countries, health strategies, and social environments.

- Synergy encourages a sharing of expertise and resources so that lessons learned in one country may be applied to others and investigators may adapt interventions to fit the new setting.
- Control for and determine environmental and social factors that may influence a particular health issue by studying similar populations and interventions.

- Publication of findings more likely to appear in higher ranked journals as comparative results from multiple countries raise a higher interest in the scientific community.

- Impact on social and policy changes as research findings from international research consortia carry prestige and high probability to bring about required policy changes.

Traditionally, collaborations and co-authorships occur as a result of economic dependence, a desire for mutual social influence and intellectual influence [7]. However, regionally based factors have proven to play an arguably more influential role in increasing the likelihood that countries collaborate. When establishing research networks, countries and institutional partners often "cluster", a feature related to geographical proximity and historical relationships [15]. Factors relating to geopolitics, a country's history, language, cultural tradition and similarity with collaborating countries play a significant role when establishing a successful network [7].

\section{Why Focus on Energy Security and Health Protection?}

At our initial planning meeting for the GEOHealth Hub, consortium members selected the research theme, «Energy Security and Health Protection» by consensus. The reason for this consensus is obvious: Ukraine faces critical choices regarding its energy security. These choices have been made even more urgent due to current events in Crimea and Donbas. The extraction and use of different forms of energy pose specific occupational and environmental health risks. These risks needed to be identified, quantified, and incorporated into energy and health policy in Ukraine. Half of Ukraine's total energy consumption comes from natural gas [12]. Natural gas production peaked at $68.7 \mathrm{~cm}$ in 1975 then declined to between 18-21 bcm/year [5]. Ukraine became heavily dependent on Russian natural gas imports that account for 75-80\% of imports [12]. A Russian-imposed embargo on selling natural gas to Ukraine would have a profound, immediate effect before Ukraine could switch to other forms of energy. Fortunately Ukraine has some of the largest shale gas deposits in Eurasia 
and Europe, estimated at 10-30 trillion cubic meters though these remain to be exploited [12]. In terms of oil, $85-90 \%$ of existing oil deposits are depleted and exploration of new fields has been insufficient. Ukraine imports oil from Belarus, Russia and Kazakhstan [5]. While Ukraine was historically rich with coal, many of these deposits are in the Donbas, which is currently in political turmoil. Extraction of coal is expensive and has lower productivity than other energy sources [19]. Nevertheless, given the situation with natural gas, the future development of thermal power will require increased dependence on coal [9]. The nuclear power industry in Ukraine has suffered because of the 1986 Chernobyl accident. Ukraine is heavily dependent on nuclear energy - it has 15 reactors generating about half of its electricity [18]. «A major increase in electricity demand to 307 billion $\mathrm{kWh}$ per year by 2020 and 420 billion kWh by 2030 is envisaged, and government policy was to continue supplying half of this from nuclear power. This would have required 29.5 GWe of nuclear capacity in 2030, up from 13.9 GWe (13.2 GWe net) now. Interruptions in natural gas supply from Russia in January 2006 sharply focused attention on the need for greater energy security and the role of nuclear power in achieving this. A nuclear power strategy involving building and commissioning 11 new reactors with total capacity of 16.5 GWe (and 9 replacement units totaling $10.5 \mathrm{GWe}$ ) to more than double nuclear capacity by 2030 was approved by the government in 2006 to enhance Ukraine's energy independence» [18].

Ukraine is also investigating alternative forms of energy such as biofuels, wind farms, and mini hydroelectric stations.

All of these different forms of energy carry specific occupational and environmental health risks. Increased reliance on coal raises the risk of occupational injuries, pneumoconiosis, air pollution, and global warming. The extraction of shale gas poses the risk of contamination of ground water. The prolongation of the life of aging nuclear power plants poses risks to nuclear plant workers and the community. Effective energy policy requires research, both basic and translational, and communication of risks and benefits of different energy alternatives to policymakers.

\section{Network Vision}

The aim of creating an Energy Security and Health Protection research consortium is to evolve the net- work of participating institutions into a knowledge creating community. The establishment of an international research network «hub» would ideally operate on the basis that partners will «no longer compete among themselves upward in terms of adding coauthorship reputation, but compete in terms of building networks of intellectual followers of the next generation» [15]. This encourages competitiveness to only exist among researchers seeking to work with those who offer the greatest potential of creating new knowledge.

In order to promote this goal of cooperation over competition, we propose an equity-based governance framework for the GEOHub. One such framework that has proven successful in other international research consortia is a lateral alliance, which encourages organizations to pool resources in the pursuit of mutually beneficial goals and interests. [4]. It rests on the foundation of interdependence among all partners to meet key research needs of each institution; effective and regular communication between partners; mutual adaptation and collective problem solving for consensus agreements for both internal and external issues; and no dictation on behalf of other institutions [15]. In a lateral alliance consortium, each member retains full control over their own organization; consortium members collaborate in areas of shared interest. While one member may house the secretariat of the consortium, it is important that all partners are equal. An equal partnership arises if all members maintain both a shared ideology and are involved on joint financial proposals to utilize funding. Partnerships and consortia do not acquire funding by mere existence, but involvement in joint proposals is an integral part to improve the likelihood of receiving funding [8]. The relationships between members are agreed to in a Memorandum of Understanding helps that establishes a collaboration agreement, outline the expectations for each partner on its role in supporting development of capacity in research, research knowledge, training and communication of research [8]. Research and network collaboration efforts should be shared across the institution to engage not only key scientific researchers but also staff involvement to build trustful mentorships. Being attentive to differing institutional needs, capacities, and strengths is vital to minimize brain drain and encourage an internal strengthening of consortia's institutional partners [8]. 


\section{Data Sharing Policy}

Creating policies for data dissemination and use is a vital component in the formation of international research consortium to ensure optimal translation of scientific findings while simultaneously safeguarding intellectual property. Data sharing policies are sometimes perceived by consortium partners as biased towards interests of more influential partners, those with more access to resources. Policies should involve all collaborating partners when creating the data sharing agreement to ensure that data can be accessed and interpreted by all. Affluent countries involved in partnership are advised to refrain from exploiting the common database to publish research that can be shared amongst partners [11].

Policies for data sharing must be sensitive and overcome researchers' reluctance to share data as perceived disadvantages. Disadvantages have been viewed as $[10,11]$ :

- Loss of academic advantage and independence;

- The possibility that their work may be misused, misinterpreted, or misrepresented;

- The loss of intellectual property;

- And an increased workload for administration and data management.

Several web-based models for archiving and sharing research data exist, and recognize the advantages and disadvantages relating to control and access for each method [10]. As outlined by the WHO bulletin, these models include:

- The centralized model - This portal provides links to databases stored in the institutions that created them. However, this portal does not manage access to databases or data transfer because these functions remain in the control of the primary researchers and institutions. This model is costefficient as it provide links to data archives to several locations. In addition, researchers retain control over sharing personal data and its reuse. However there is no central data repository, and data preservation standards cannot be assured and consistent access cannot be guaranteed;

- Centralized archiving with disseminated expert support - This model has a single repository that archives and manages access to data. Researchers are required to submit their databases to this governing repository. Advantages include: costeffective infrastructure use; the opportunity to train and retain highly skilled data archivists; the removal of the burden of data archiving from institutions; and provision of a «one-stop shop» for researchers within the consortia seeking data for secondary use. Disadvantages include: relinquishing the researchers' ability to monitor, influence or participate in the secondary use of their data. Centralized data archives are also cited as not providing the same expert knowledge of research databases as the generating institutions or specialized repositories;

- Subject-focused repositories - This model includes the advantages of a centralized data archiving and access, as well as the support of experts drawn from the participating institutions. The diverse expertise offers additional support however disadvantages to this model draw concerns over loss of control and the requirement of providing ongoing expert support;

- Portal models - Such databases are archived in repositories that specialize in specific research areas. However, despite its cost-effectiveness, this model arguably works against interdisciplinary collaboration because boundaries between research areas are not always explicitly defined, making specific databases harder to locate.

\section{Data Committee}

A central Data Committee or Data Resource Coordinating Center is a common strategy used by international research consortia to manage data and ensure data policy procedures are abided [14]. Data committees are often comprised of consortium members and/or independent experts from each country. This committee assumes the responsibility to monitor discrepancy in data collection, control the authorization to publish data, grant access to data, limit how data can be used, ultimately demarcates resources to determine which information is shared across the consortium and which samples or datasets remain in the hands of the individual investigators [10]. Creating a Data Committee board aids in overcoming the challenge of deciding where to house the data, who will have access, how to access, and how to return significant findings to the original PI [16].

Intellectual property rights management is an important component of research consortia that can assist to maximize translation of research findings into products such as pharmaceuticals or vaccines [2]. The consortium should set an overarching policy and 
procedure as a standard for intellectual property rights that observes the participating institutional partners' individual policies [3].

\section{IRB Guidelines}

Ethical concerns arise when working with data sets and biospecimens exchanged between a large network of research institutes. Consortia projects conducted in one country may reflect their own country's different legal and cultural norms, presenting difficulties in harmonizing consortium's procedures [16]. Deciding how to keep individual research results private and anonymous is reliant on an agreed consortium wide policy and approved IRB training. One way that has reduced potential risks to individuals is to only publicly release pooled data by the consortia to maintain anonymity when disseminating preliminary findings [2]. Another is to determine whether research participants' samples will be housed in a central repository, maintained by each member project, or have the option for an opt out of returning results at the consortium level [16].

When local research projects become part of an international consortium, another dimension of complexity is added to developing a comprehensive and understandable consent form. These consent forms must include the goals and requirements of the project as well as the consortium [16]. It is encouraged to use model templates to assist with harmonizing consent requirements to ensure conformity across the individual research projects. This clarifies what consent material elements are necessary to include on behalf of the local institutional and ethics review boards, in addition to the requirements of the international consortium [16].

\section{Evaluating Consortia Performance}

Internal network evaluation is an integral part of consortium-based research [4]. Conducting an evaluation established a feedback loop to rapidly identify and correct problems within the network structure or functioning before it interferes with research. Periodic internal evaluation has proven valuable to perform in five domains: 1) extent of collaboration and quality of communication; 2) performance of projects and infrastructure; 3) data quality; 4) scientific productivity; 5) impact on member organizations [4]. Assessment tools can include an annual survey of consortia stake- holders and staff, in addition to yearly progress reports on project teams, accrual of publications and presentations, and the use of infrastructure resources to demonstrate performance.

\section{Recommendations for a GEOHealth Hub in Ukraine}

Based on the results of our planning efforts, the U.Sbased authors several recommendations the proposed GEOHealth Hub in Ukraine. We propose that the GEOHealth Hub adopt a lateral alliance structure. Given the current political situation in Ukraine, we recommend that the secretariat and fiscal administration of the consortium be based in the Scientific and Technical Center of Ukraine (STCU). STCU was established by the governments of Ukraine, the United States, and the European Union for the specific purpose of facilitating international research collaborations. STCU continues to manage bi-national research programs between the U.S. National Institutes of Health and Ukrainian research institutions. As such they have the experience and capability to manage complex international collaborations. The consortium should have an international Advisory Committee that would include key stakeholders in Ukraine, such as the Ministries of Health, Energy, and Environment. The Advisory Community should also include impacted stakeholders, such as representatives from non-governmental organizations focused on energy security, environmental health, and occupational health. The functioning of the consortium should be managed by a Steering Committee that includes representatives from all member institutions. The Secretariat should have dedicated, fulltime persons, ideally researchers involved in jointly funded projects, who would serve as links to committees and institutions to provide guidance on issues related to research and consortia function.

We recommend that the consortium establish a data management core that would coordinate quality control of data management and provide statistical and computing services as requested by consortium members. While each participating member is likely to maintain their own data management capability, a data management core is still necessary to provide oversight and quality control. The consortium should set general principles for data sharing for joint research projects in addition to rules that individual institutions might already have. 
Equitable sharing of opportunities for research and publications is a key success factor in international research consortia. The GEOHub should advocate for equitable sharing of new research opportunities; encourage joint authorships; and advocate for an equitable sharing of publications. In addition to a «top-down» research agenda, in which the Steering Committee prioritizes research based on Advisory Committee recommendations, the consortium should encourage «bottom-up» research proposals from individual scientists. This combined approach is can simultaneously address identified research needs while encouraging scientific innovation.

All researchers involved in the consortium must be trained and certified in the ethical conduct of research. Member institutions should maintain their own Institutional Review Boards (IRBs) whenever feasible, or defer to other IRBs for review of their research proposals.

\section{References}

1. Promoting Public Health: Benefits and Challenges of Europeanwide Research Consortium on Student Health / Ansari W. E., Maxwell A. E., Mikolajczyk R.T. [et al.] // Central European Journal of Public Health. 2007. - V. 15, № 2. - P. 58-65.

2. Chokshi D. A. Data sharing and intellectual property in a genomic epidemiology network: policies for large-scale research collaboration / Chokshi D. A., Parker M., Kwiatkowski D. P. // Bulletin of the World Health Organization. - 2006. - V. 84, № 5. - P. 382-387.

3. FreshwaterD. International Research Collaboration: Issues, benefits and challenges of the global network / Freshwater D., Sherwood G., Drury V. // Journal of Research in Nursing. - 2006. - V. 11, № 4. - P. 295-303.

4. Greene S. Measuring and Improving Performance in Multicenter Research Consortia / Greene S., Hart G., Wagner E. // Journal of the National Cancer Institute Monographs. - 2005. - V. 35 - P. 26-32.

5. International Energy Agency. Ukraine 2012 // http: / /www.iea.org/publications / freepublications / publication/Ukraine2012_free.pdf.

6. Kiehntopf M. Biobanking and international interoperability: samples / Kiehntopf M., Krawczak M. / / Human Genetics. - 2011. - V. 130. - P. 369-376.

7. Luukkonen $\mathrm{T}$. Understanding Patterns of International Scientific Collaboration / Luukkonen T., Persson O. // Science, Technology \& Human Values. 1992. - V. 17. - P. 101-126.

8. Mayhew S. H. Developing health systems research capacities through north-south partnerships: An evaluation of collaboration with South Africa and
Communication is essential to the success of international research collaborations. Communication should occur through a combination of face-to-face meetings, conference calls, web communications, and periodic newsletters that focus on consortium accomplishments and opportunities. The consortium should facilitate communication at all levels, from the Steering Committee down to the individual researcher. Opportunities for innovation often arise when researchers from different backgrounds are asked to look at a research question from different perspectives.

The establishment of a research consortium is not an end in itself. The ultimate goal is to conduct high quality research that informs the development of energy policies in Ukraine that not only guarantee energy security, but also protect the health of workers, the communities, and the environment. An effective international research consortium is simply a means to that end.

Thailand / Mayhew S. H., Doherty J., Pitayarangsarit S. // Health Research and Policy Systems. - 2008. - V. 6, № 8 .

9. Ministry of Energy and Coal Industry of Ukraine. Statement on Security of Energy Supply of Ukraine / Januray 2012. - http://www.energy-community.org/ pls/portal/docs/1676177.PDF.

10. Rani M. Systematic archiving and access to health research data: rationale, current status and way forward / Rani M., Buckley B. S. // Bulletin of the World Health Organization. - 2012. - V. 90, № 12. - P. 932-939.

11. Singh J. A. Intra-consortium data sharing in multi-national, multi-institutional genomic studies: gaps and guidance / Singh J. A., Daar A. S. / The HUGO journal. - 2009. - V. 3, № 1-4. - P. 11-14.

12. Umbach F. Ukraine's Energy Security Challenges: Implications for the EU / Singh J. A., Daar A. S. // Open Ukraine: Changing Course Towards a European Future http://transatlantic.sais-jhu.edu/publications/books / Open_Ukraine/05.Umbach.pdf

13. Vaught J. B. International Efforts to Develop Biospecimen Best Practices / Vaught J. B., Caboux E., Hainaut P. // Cancer Epidemiological Biomarkers Prevention. - 2010.- V. 19, № 4. - P. 912-915.

14. Building a research consortium of large health systems: the Cancer Research Network / Wagner E. H., Greene S. M., Hart G. [et al.] // Journal of the National Cancer Institute Monographs. - 2005. - V. 35. - P. 3-11.

15. Wagner C. S. Network structure, self-organization, and the growth of international collaboration in science / Wagner C. S., Leydesdorff L. // Research policy. - 2005. V. 34, № 10. - P. 1608-1618. 
16. Wallace S. E. The Needle in the Haystack: International Consortia and the Return of Individual Research Results / Wallace S. E. // Journal of Law, Medicine \& Ethics. - 2011. - P. 631-639.

17. Walport M., Brest P. Sharing research data to improve public health / Walport M., Brest P. // The Lancet. - 2011. - V. 377, № 9765. - P. 537-539.
18. World Nuclear Association. Nuclear Power in Ukraine / / http://www.world-nuclear.org/info/CountryProfiles/Countries-T-Z/Ukraine/.

19. Zhovkva I. Energy Security Challenges in Ukraine: A Snaphsot 2010 / Zhovkva I. / / International Centre for Policy Studies - http://pasos.org/ wp-content/archive/Energy_Strat_Eng.pdf.

Григорчук А. О.1,2, Коэишыкий Т.' ', Іваник К. Н.', ЕАісон М.' , АәрАинсыкий О.' , АәрАинсыка І.2 МІХКНАРОАНИЙ КОНСОРШІУ З АОСАІАХКЕННЯ ЕНЕРГЕТИЧНОї БЕВПЕКИ ТА ЗАХИСТУ ЗАОРОВ'Я НАСЕАЕННЯ УКРАÏHИ: ПОГАЯА США НА ПЕРСПЕКТИВУ

'Шентр Глобального ЗАоров'я, МеАичний колеАж Імиінойського Університету, Чикаго, США

Школа громадського здоров'я, Імінойський Університет в м. Чикаго, США

Іллінойський Університет у м. Чикаго в партнерстві з українським Інститутом медицини праці НАМН України, Інститутом гігієни та медичної екології імені О. М. Марзєєва, Інститутом ендокринології та обміну речовин В. П. Комісаренка та Національним науковим центром з радіаційної медицини НАМН України започаткували планування та створення Міжнародного Консорціуму для вивчення енергетичної безпеки та захисту здоров'я населення України. Підтримка в плануванні Центру з охорони навколишнього середовища та професійного здоров’я надається Міжнародним центром Фогарті при Національному інституті здоров'я США. У статті представлена сучасна точка зору США відносно факторів успіху та викликів для впровадження такого Консорціуму.

Ключові слова: Міжнародний дослідницький консорціум, захист здоров'я населення, енергетична безпека, латеральний альянс

\section{Григорчук А. О.',2, Козишкий Т. ${ }^{2}$, Иваник К. Н.' , ЭАисон М.', АәрАинский О.', АәрАинская И. ${ }^{2}$ МЕХКАУНАРОАНЫЙ КОНСОРЩИУМ ПО ИССАЕАОВАНИЮ ЭНЕРГЕТИЧЕСКОЙ БЕВОПАСНОСТИ И ЗАШИТЕ ЗАОРОВЬЯ НАСЕАЕНИЯ УКРАИНЫ: ТОЧКА ЗРЕНИЯ США НА ПЕРСПЕКТИВУ}

'Шентр глобального зАоровья, Медицинский коммеАж Иминойского Университета, Чикаго, США ¿Школа обшественного зАоровья, Имиинойский университет в г. Чикаго, США

Иллинойский Университет в г. Чикаго в партнерстве с Институтом медицины труда НАМН Украины, Институтом гигиены и медицинской экологии имени А. Н. Марзеева, Институтом эндокринологии и обмена веществ имени В. П. Комиссаренко, а также Национальным научным центром радиационной медицины НАМН Украины инициировали планирование и создание Международного Консорциума по исследованию энергетической безопасности и защите здоровья населения Украины. Поддержка в планировании Центра по охране окружающей среды и профессионального здоровья предоставляется Международным Центром Фогарти Национального института здоровья США. В статье представлена современная точка зрения США в отношении факторов успеха и вызывов при внедрении такого Консорциума.

Ключевые слова: Международный исследовательский консорциум, защита здоровья населения, энергетическая безопасность, латеральный альянс

Надійшла: 09.09.2014 p.

Контактна особа: Григорчук Д. О., Центр глобального здоров'я, Медицинський коледж Ілінойського Університету, Чикаго, США. 